\title{
RECOMBINATION PECULIARITIES IN DOPED Ge *
}

\author{
E. Gaubas ${ }^{\mathrm{a}}$, A. Uleckas ${ }^{\mathrm{a}}$, J. Vanhellemont ${ }^{\mathrm{b}}$, and A. Theuwis ${ }^{\mathrm{c}, \mathrm{d}}$ \\ ${ }^{a}$ Institute of Materials Science and Applied Research, Vilnius University, Saulètekio 10, LT-10223, Vilnius \\ E-mail: eugenijus.gaubas@ff.vu.lt \\ ${ }^{\mathrm{b}}$ Department of Solid State Sciences, Ghent University, Krijgslaan 281 S1, B-9000 Ghent, Belgium \\ ${ }^{\mathrm{c}}$ Umicore Electro-Optic Materials, Watertorenstraat 33, B-2250 Olen, Belgium \\ d Present address: AMI Semiconductor Belgium BVBA, Westerring 15, B-9700 Oudenaarde, Belgium
}

Received 9 July 2007

\begin{abstract}
Peculiarities of recombination processes in Czochralski $(\mathrm{Cz})$ grown $\mathrm{Ge}$ wafers of $n$ - and $p$-type material are investigated. Recombination characteristics in $n$-Ge implanted with $\mathrm{Co}, \mathrm{Fe}, \mathrm{Ti}, \mathrm{Ni}$, and $\mathrm{Cr}$ are studied before and after annealing. A decrease of the carrier lifetime with increasing doping density has been observed both for $n$ - and $p$-type Ge using the same excitation level. This decrease is analysed by assuming an increase of the concentration of recombination centres with increasing doping density. Introduction of metal impurities by ion implantation leads to a decrease of carrier lifetime values. The increase of lifetime with increasing excitation level in the metal-implanted samples implies the formation of acceptor-like slow recombination centres. A photoconductivity quenching effect has been observed in all the implanted samples indicating the existence of centres of fast recombination, related with metal implants, competing with those of slow recombination.
\end{abstract}

Keywords: recombination, photoconductivity quenching, germanium

PACS: $61.72 . J i, 61.82 . \mathrm{Fk}, 72.40 .+\mathrm{w}$

\section{Introduction}

The renewed interest for applications of Ge substrates and thin films, with a wide range of densities and species of introduced dopants, from high purity Ge for particle detector applications to highly doped Ge substrates in solar cells technology, necessitates investigations of the carrier recombination peculiarities in Ge. Complementary, there is a strong interest to use Ge layers as active device layers in deep submicron CMOS technology for the production of high frequency devices. Parameters of the device active layers are commonly modified by implantations, however, carrier lifetime variations in heavily implanted Ge have been poorly examined so far.

In this work, peculiarities of recombination processes in $\mathrm{Cz}$ and float zone (FZ) grown Ge wafers of $n$-type ( $\mathrm{Sb}$ doped) and $p$-type (Ga doped) material from different suppliers are investigated. The observations can be explained well by assuming that the density of recombination centres increases with doping. The recombination characteristics in $n$-Ge implanted with $\mathrm{Co}, \mathrm{Fe}, \mathrm{Ti}, \mathrm{Ni}$, and $\mathrm{Cr}$ are also studied before and af-

\footnotetext{
* The report presented at the 37th Lithuanian National Physics Conference, 11-13 June 2007, Vilnius, Lithuania.
}

ter thermal annealing. It is shown that high densities of implantation related defects can cause a redistribution of carrier capture and recombination flows by trap filling. The electrical peculiarities of the metal-induced recombination defects depend on the thermal processing of material after metal implantation. The annealing temperature and duration determine fast in-/ outdiffusion of the implants as well as their state (interstitial/ substitutional / clustered) within the lattice. The carrier trapping and photoconductivity quenching effects leading to variations of minority and majority carrier lifetimes are determined by the interplay of grownin and implantation induced slow and fast recombination centres.

\section{Samples}

$\mathrm{Cz}$ and FZ grown Ge wafers of $n$-type (Sb doped) and $p$-type (Ga doped) material samples from different suppliers are investigated in order to study carrier lifetime as a function of doping and excitation level. Wafers with a thickness of 175 and $560 \mu \mathrm{m}$ were used in this study. Materials with initial resistivity ranging from 33 to $38 \Omega \cdot \mathrm{cm}$ were used for the metal implantation experiments. $\mathrm{Co}, \mathrm{Fe}, \mathrm{Ti}, \mathrm{Ni}$, and $\mathrm{Cr}$ impurities 
were introduced into $n$-Ge by ion implantation in order to reveal the impact of metal impurities on the recombination properties of Ge. The implantations were performed using an energy of $90 \mathrm{keV}$ and fluences of $5 \cdot 10^{13}$ and $5 \cdot 10^{14} \mathrm{ion} / \mathrm{cm}^{2}$, respectively. The initial implantation profiles were at about $45 \mathrm{~nm}$ below the wafer surface with peak concentrations above $5 \cdot 10^{19} \mathrm{~cm}^{-3}$. All the implanted samples were annealed at $500^{\circ} \mathrm{C}$ for $5 \mathrm{~min}$, while the Ni-implanted wafers were treated at $350^{\circ} \mathrm{C}$ for $1 \mathrm{~min}$ and at $700^{\circ} \mathrm{C}$ for $60 \mathrm{~min}$, in order to remove the implantation damage and to facilitate diffusion. The sample surfaces were passivated by iodine-containing varnish to suppress surface recombination.

\section{Experimental technique}

The excess carrier decay transients were examined by microwave reflection (MWR) probing [1] of the pulse-excited area of the sample. The MWR probing was carried out by using a slit or a coaxial needletip antenna. The excess carriers were generated by a $1062 \mathrm{~nm}$ wavelength laser beam using pulses of $500 \mathrm{ps}$. The carrier decay transients, averaged over the carrier diffusion length, were probed by microwaves in parallel with laser beam geometry by using a MW slit antenna. The lifetime depth profiles were examined using a collimated beam through an optical fibre and a MW needle antenna whereby the sample was translated relatively to the intersection point of the MW antennafibre beam over the wafer cross-section using a micro- step stage. The excess carrier decay was examined as a function of the excitation level, to determine the parameters of the dominant recombination centres and mechanisms. Steady-state infrared broad-band bias illumination (IRBI) was complementary utilized to suppress carrier trapping by shallow levels or to vary the filling of deep levels.

\section{Results and discussion}

A decrease of carrier lifetime with doping density has been observed for as-grown $n$ - and $p$-type Ge, as illustrated in Fig. 1 for $p$-Ge for a constant excitation level. Experimental carrier lifetime variations dependent on dopant concentration were simulated for $p$-Ge assuming existence of a dominant recombination centre with activation energy, concentration, and capture cross-section of $E_{\mathrm{R}}=0.3 \mathrm{eV}, M_{\mathrm{R}}=5 \cdot 10^{12} \mathrm{~cm}^{-3}$, $\sigma_{p}=4 \cdot 10^{-16} \mathrm{~cm}^{2}, \sigma_{n}=10^{-14} \mathrm{~cm}^{2}$, respectively. The measured variation of recombination lifetime agrees well with $\tau_{\mathrm{SRH}}$ for low injection level up to a dopant concentration $n_{\text {dop }}$ of about $10^{16} \mathrm{~cm}^{-3}$. The observed decrease of lifetime for $n_{\text {dop }}>10^{16} \mathrm{~cm}^{-3}$ is described well by the relation $\tau_{\mathrm{R}}=\tau_{\mathrm{SRH}} /\left(1+n_{\mathrm{dop}} / n_{\mathrm{thr}}\right)$, assuming a threshold doping density $n_{\mathrm{thr}}$ and an increase of the concentration of recombination centres being proportional to the dopant concentration. The influence of the varying recombination centre concentration cannot be observed below the threshold concentration of dopants. Assuming $n_{\mathrm{thr}}=4 \cdot 10^{16} \mathrm{~cm}^{-3}$ and calculating $\tau_{\mathrm{SRH}}$ for a fixed value of the product $\sigma_{p, n} N_{\mathrm{R}}$ of

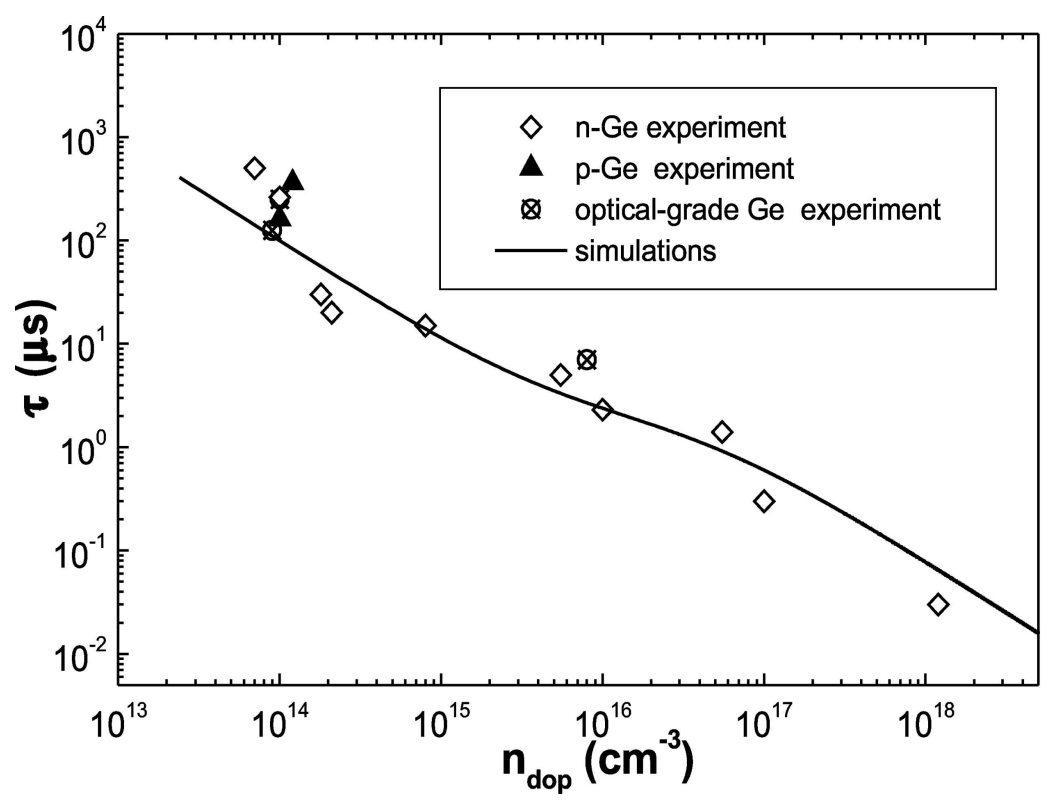

Fig. 1. Carrier lifetime variations in Ge measured at low excitation density as a function of doping density. The solid line shows a simulation assuming a dominant single-species recombination centre and a fixed injection level $k=n_{\text {exc }} / n_{\text {dop }}=0.01$. 


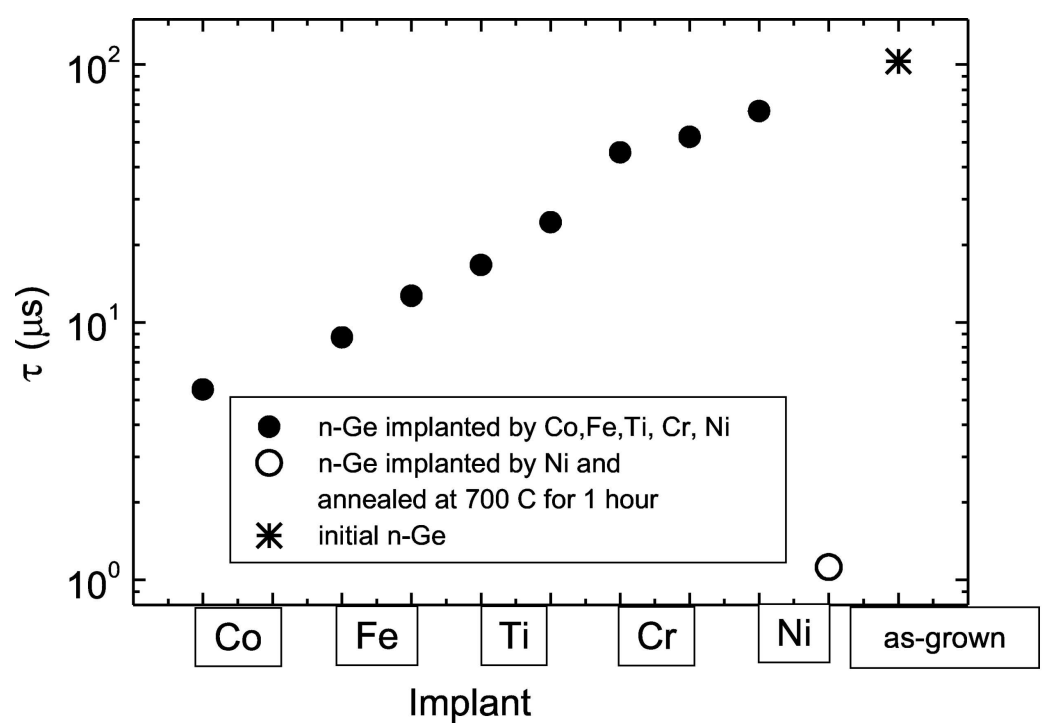

Fig. 2. Variations of carrier lifetime in $n$-Ge with metal species and heat treatment.

trap concentration $N_{\mathrm{R}}$ and trap capture cross-section $\sigma_{p, n}$ for holes $(p)$ and electrons $(n)$, respectively, the simulated recombination lifetime decrease is in a good agreement with the experimental results obtained at low excitation level as illustrated in Fig. 1. These carrier lifetime variations, assuming a single dominant recombination centre with energy level located nearby the mid-band-gap of Ge, imply an increase of concentration of recombination centres with increasing doping density in the as-grown Ge material. The estimated threshold value $n_{\text {thr }}$ is also in agreement with the saturation value obtained at the excitation density $n_{\text {exc }}$ of about $10^{16} \mathrm{~cm}^{-3}$ as was determined for $3 \Omega \cdot \mathrm{cm} \mathrm{Ge}$ [2] using investigations of the trap filling dependence on excitation level. However, the assumption of a single dominant centre and of Shockley-Read-Hall (SRH) statistics can be used only as a first-order iteration for the study of the lifetime variation in the as-grown $\mathrm{Ge}$ material. The trapping and trap-filling effects revealed in our experiments indicate a more complex system of defects, whereby excess carrier flows are redistributed by a set of deep and shallow traps.

Introduction of metal impurities by implantation leads to a decrease of carrier lifetime values compared to those in the as-grown material, as shown in Fig. 2. The figure also reveals that the values of carrier lifetime in the as-implanted samples significantly depend on the implanted metals. This dependence measured for the same excitation density roughly indicates the efficiency of the metal induced traps in changing the minority carrier lifetime.

However, variations of excess carrier lifetime with excitation density have been revealed for all the im-

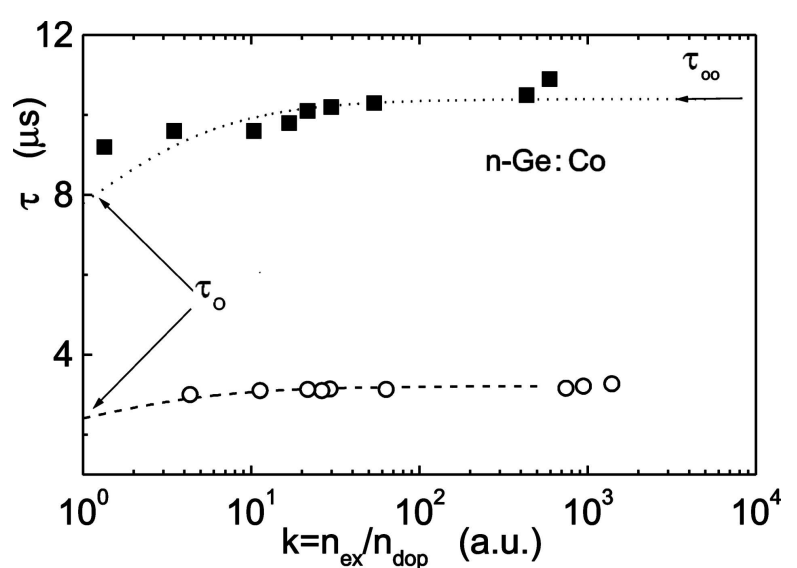

Fig. 3. Carrier lifetime variations in Ge with excitation density in Co-implanted $n$-Ge obtained for different implantation fluences. Symbols show experimental data: o for $5 \cdot 10^{13}$, $\mathbf{a}$ for $5 \cdot 10^{14}$ ion $/ \mathrm{cm}^{2}$. Lines represent simulations using SRH statistics: dashed line for $\sigma_{n} N_{\mathrm{R}}=1.5 \cdot 10^{-2} \mathrm{~cm}^{-1}, \sigma_{p} N_{\mathrm{R}}=10^{-1} \mathrm{~cm}^{-1}$, dotted line for $\sigma_{n} N_{\mathrm{R}}=3 \cdot 10^{-3} \mathrm{~cm}^{-1}, \sigma_{p} N_{\mathrm{R}}=2 \cdot 10^{-2} \mathrm{~cm}^{-1}$. $n_{0}=10^{14} \mathrm{~cm}^{-3}, E_{\mathrm{R}}=0.33 \mathrm{eV}$.

planted metals, with the most expressed dependence for Cr. Examination of low and high injection level lifetimes, as illustrated in Fig. 3 for Co-implanted $n$-Ge at different implantation fluences, allows to calculate the ratio of the capture cross-sections $\sigma_{p} / \sigma_{n}$ for minority and majority carriers, respectively, see e.g. [3-5]. From the lifetime dependence on the excitation density, the ratio of capture cross-sections $\sigma_{p} / \sigma_{n}$ has been estimated for the latter centres based on SRH statistics, as listed in Table 1. These values suggest a change of $\sigma_{p} / \sigma_{n}$ with fluence for $\mathrm{Ti}$ and $\mathrm{Cr}$ which is an indication of the acceptor-like behaviour of the metals induced centres. These lifetime variations with pulsed excitation density for a 'dark background' can 


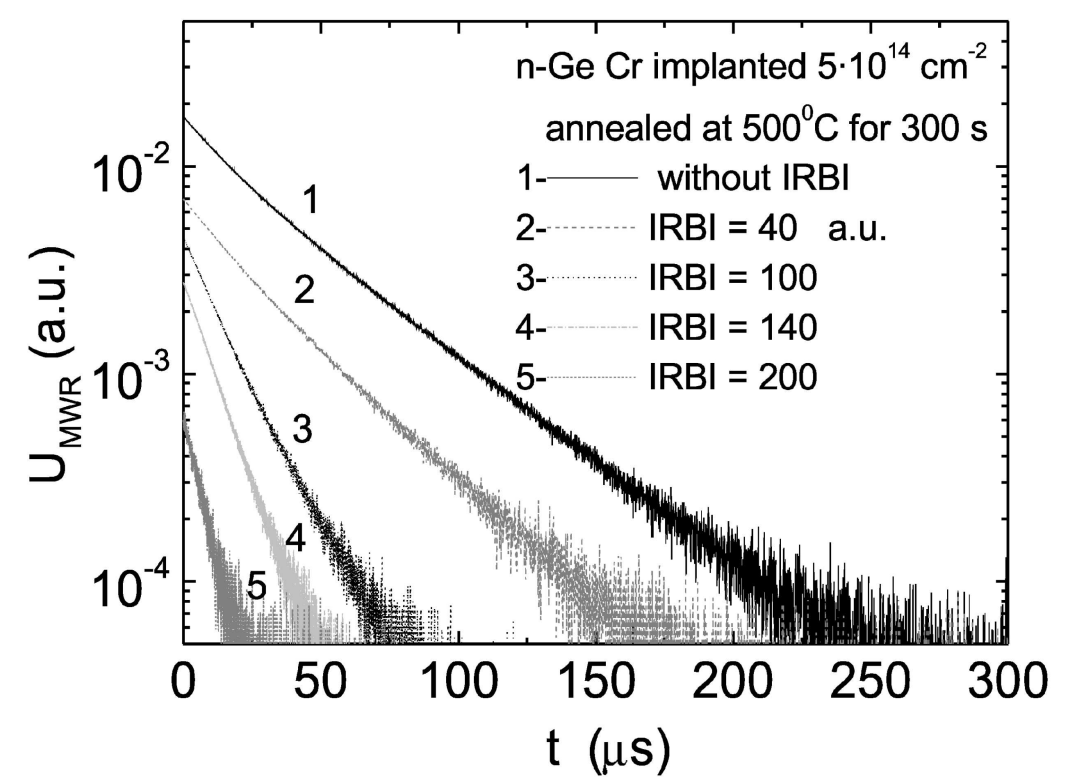

Fig. 4. Variations of carrier decay transients with infrared broad-band bias illumination intensity in a Cr-implanted sample.

Table 1. Ratio of the cross-sections of minority and majority carriers $\sigma_{p} / \sigma_{n}$ estimated using the SRH model.

\begin{tabular}{ccccc}
\hline \multirow{2}{*}{$\begin{array}{c}\text { Implantation } \\
\text { fluence }\end{array}$} & \multicolumn{5}{c}{ Metal implants } \\
\cline { 2 - 5 } & Co & $\mathrm{Fe}$ & $\mathrm{Ti}$ & $\mathrm{Cr}$ \\
\hline $5 \cdot 10^{13} \mathrm{~cm}^{-2}$ & $<1$ & $\sim 1$ & $>1$ & $>1$ \\
$5 \cdot 10^{14} \mathrm{~cm}^{-2}$ & $\sim 1$ & $>1$ & $>2$ & $>4$ \\
\hline
\end{tabular}

be qualitatively simulated and fitted to the experimental data using a simple SRH model only for mono-pulsed excitation within a rather narrow range of excitation densities. Implants of $\mathrm{Fe}$ and $\mathrm{Co}$ are the most effective minority carrier lifetime killers in $n$-Ge while $\mathrm{Cr}$ has the least influence, as deduced from simulations (made in the same manner as illustrated for Co in Fig. 3) using the trap parameters obtained from deep level transient spectroscopy (DLTS) analyses [6].

The existence of a complicated system of recombination centres in the implanted Ge material is also corroborated by a clear photoconductivity quenching (PCQ) effect that has been observed in the samples after the 350 and $500{ }^{\circ} \mathrm{C}$ annealings. The photoconductivity quenching effect has been revealed in all the implanted samples and depends on post-implantation heat-treatments. The annealing of the implanted samples leads to a decrease of the carrier lifetime and to a suppression of photoconductivity quenching. The lifetime variations as a function of the excitation density can be understood by changes of the amplitudes of 'fast' and 'slow' components within a multiexponential carrier density relaxation. Hereby the effective lifetimes are complicated functions of the pa-

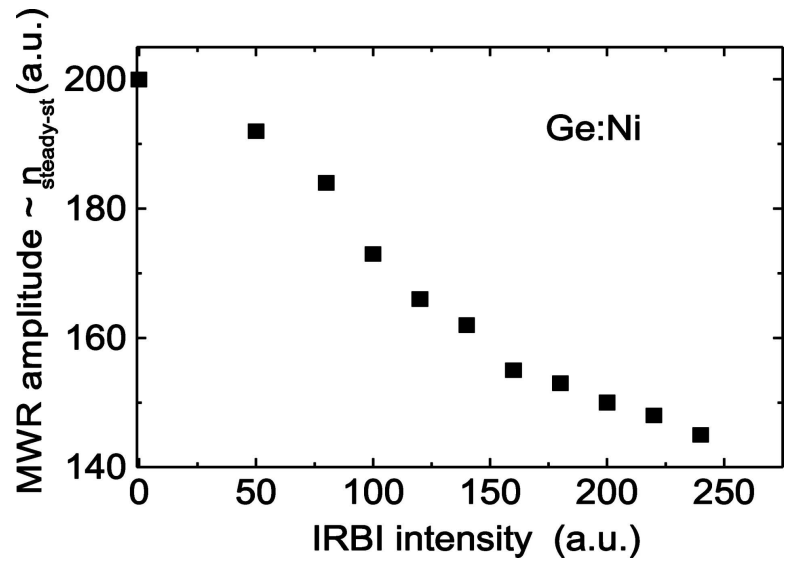

Fig. 5. Variation of the steady-state microwave reflection amplitude with infrared broad-band bias illumination intensity in $n$-Ge:Ni.

rameters of several centres. The PCQ effect is characterized by simultaneous decrease of the amplitude of the MWR signal and reduction of decay lifetime, as illustrated in Fig. 4 for a Cr-implanted sample.

The PCQ effect is mainly caused by capture of the majority carriers, as revealed from the steadystate MWR measurements illustrated in Fig. 5 for a Ni-implanted sample. A significant decrease of the steady-state MWR signal has been observed with increasing IRBI intensity clearly indicating a reduction of the majority carrier density.

The characteristics of the PCQ effect which are illustrated in Figs. 4 and 5, are specific for all the implanted samples with the range of these variations decreased going from $\mathrm{Cr}$ to Co. The simplest of the wellknown PCQ models $[7,8]$ is quantitatively described by a two-exponential [8] decay. The variation of the ratio 


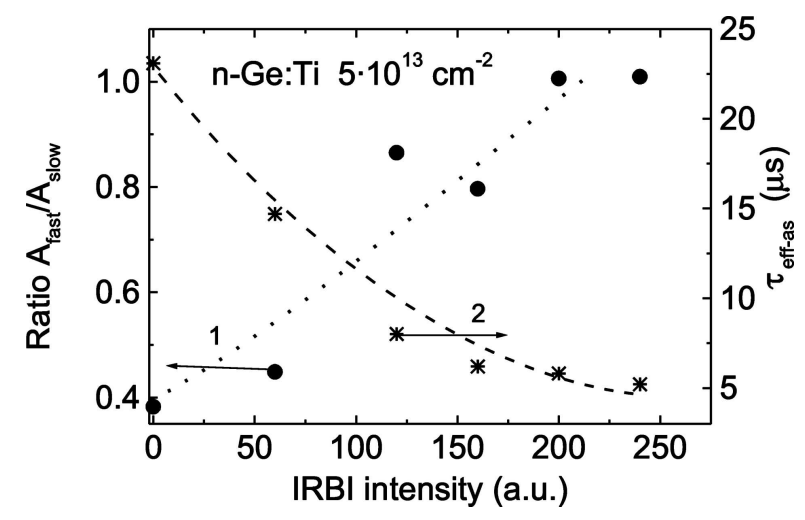

Fig. 6. Ratio of the fast and slow carrier recombination components (1) and effective lifetime within the asymptote for the Ti-implanted sample (2) estimated using a two-exponential decay model.

of the decay amplitudes with IRBI intensity, attributed to 'fast' and 'slow' recombination centres, which has been estimated by using a two-exponential decay analysis, is illustrated by curve 1 in Fig. 6 . It can be noticed that the fast component becomes dominant with increasing IRBI intensity. This determines a decrease or disappearance of the role of the 'slow' component within the transient resulting in a reduction of the effective carrier lifetime (curve 2 in Fig. 6). The lifetime values measured using the largest IRBI intensities are very close to those obtained after long-term hightemperature annealings of implanted samples.

The correlated decrease of the majority carrier density in $n$-Ge (Fig. 5) and the enhancement of the impact of 'fast' centres (Figs. 4 and 6) when filling them by IRBI imply a donor-like origin of these defects. Thus, heat treatments of implanted samples lead to an annealing or transformation of the 'slow' centres. Alternatively, the filling state of these 'slow' centres can be changed by transformation of other defects that change the position of the Fermi level relatively to that of the capture centres. In the as-implanted samples, the 'slow' centres compete with the 'fast' ones, however, the latter ones need activation by IRBI to be observable. The recombination process can be approximated by a single dominant acceptor-like centre when the 'fast' ones are inactivated.

\section{Summary}

The dependence of carrier lifetime on doping and excitation regimes has been revealed in as-grown $\mathrm{Ge}$. The observations can be explained by the SRH model in low and moderately doped material, whereby the lifetime decreases linearly with $1 / n_{\text {dop }}$ for dopant concentrations above $4 \cdot 10^{16} \mathrm{~cm}^{-3}$. This can be understood by an increase of the recombination centre concentration proportional to the dopant concentration.

The native defects act together with implantationinduced impurities causing complicated recombination characteristics dependent on excitation and annealing conditions. $\mathrm{Fe}$ and $\mathrm{Co}$ are the most effective lifetime killers in $\mathrm{Ge}$ while $\mathrm{Cr}$ has the least influence. Existence of a system of 'slow' and 'fast' recombination centres and as a consequence the appearance of the PCQ effect have been revealed in all the implanted samples whereby the lifetime variations decrease from $\mathrm{Cr}$ to Co. The acceptor-like behaviour can be ascribed to 'slow' centres while donor-type defects should be attributed to 'fast' ones. The latter ones are responsible for the fast decrease of majority carrier densities under annealings and IRBI.

\section{Acknowledgement}

This work was supported by the Lithuanian State Science and Studies Foundation.

\section{References}

[1] E. Gaubas, Transient absorption techniques for investigation of recombination properties in semiconductor materials, Lithuanian J. Phys. 43, 145-165 (2003).

[2] E. Gaubas, M. Bauža, A. Uleckas, and J. Vanhellemont, Carrier lifetime studies in Ge using microwave and infrared light techniques, Mater. Sci. Semicond. Processing 9, 781-787 (2006).

[3] J.S. Blakemore, Semiconductor Statistics (Pergamon Press, New York, 1962).

[4] B.J. Baliga, Power Semiconductor Devices (PWS Publishing Company, Boston, 1996).

[5] V.K. Khanna, Physical understanding and technological control of carrier lifetimes in semiconductor materials and devices: A critique of conceptual development, state of the art and applications, Prog. Quantum Electron. 29, 59-163 (2005).

[6] S. Forment, J. Vanhellemont, P. Clauws, J. Van Steenbergen, S. Sioncke, M. Meuris, E. Simoen, and A. Theuwis, A deep level transient spectroscopy study of transition metals in $n$-type germanium, Mater. Sci. Semicond. Processing 9, 559-563 (2006).

[7] A. Rose, Concepts in Photoconductivity and Allied Problems (Interscience Publishers-John Wiley \& Sons, New York-London, 1963).

[8] V. Lashkarev, A. Lyubchenko, and M. Sheynkman, Non-Equilibrium Processes in Photo-Conductors (Naukova Dumka, Kiev, 1981) [in Russian]. 


\title{
REKOMBINACIJOS YPATUMAI GERMANYJE SU PRIEMAIŠOMIS
}

\author{
E. Gaubas ${ }^{\text {a }}$, A. Uleckas ${ }^{\text {a }}$, J. Vanhellemont ${ }^{\mathrm{b}}$, A. Theuwis ${ }^{\mathrm{c}, \mathrm{d}}$

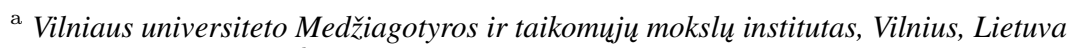 \\ ${ }^{\mathrm{b}}$ Gento universitetas, Gentas, Belgija \\ ${ }^{\mathrm{c}}$ Umicore Electro-Optic Materials, Olen, Belgija \\ ${ }^{\mathrm{d}}$ AMI Semiconductor Belgium BVBA, Oudenaarde, Belgija
}

\section{Santrauka}

Nenuostoviosios mikrobangu sugerties metodu ištirta skirtingu metalų ir jų koncentracijų itaka krūvininku gyvavimo trukmei germanyje. Stebèti ir ištirti krūvininku prilipimo, fotolaidumo gesinimo reiškiniai, taip pat išnagrinèta implantuotais metalais sukurtu rekombinacijos procesus nulemiančių defektų kaita, keičiant ban- dinių iškaitinimo temperatūrą. Atskleista sudètinga defektų lygmenų, - išeities medžiagos ir priskirtinu implantams, - sistema, lemianti krūvininkų prilipimo ir rekombinacijos vyksmus. Tai sukelia rekombinacijos srautu persiskirtymą ir fotolaidumo charakteristikų netiesiškumo bei fotolaidumo gesinimo reiškinius, kurie mažina pagrindinių krūvininkų koncentraciją ir gyvavimo trukmę. 